Corresponding author: lesb@mail.nih.gov

(C) 2020 Biesecker et al. This article is distributed under the terms of the Creative Commons Attribution-NonCommercial License, which permits reuse and redistribution, except for commercial purposes, provided that the original author and source are credited.

Ontology terms: abnormal plantar dermatoglyphics; abnormal subcutaneous fat tissue distribution; attention deficit hyperactivity disorder; hypercoagulability; hypertrophy of skin of soles; intellectual disability; moderate; macrodactyly of finger; macrodactyly of toe; neoplasia of the male external genitalia; ovarian neoplasm; overgrowth; postnatal macrocephaly; prominent veins on trunk; proportionate tall stature; testicular neoplasm; venous malformation

Published by Cold Spring Harbor Laboratory Press

doi:10.1101/mcs.a004549

\section{Clinical report: one year of treatment of Proteus syndrome with miransertib (ARQ 092)}

\author{
Leslie G. Biesecker, ${ }^{1}$ Matthew Edwards, ${ }^{2,3}$ Sheridan O'Donnell, ${ }^{2}$ Paula Doherty, ${ }^{4}$ \\ Thomas MacDougall, ${ }^{5}$ Kate Tith, ${ }^{6}$ Julia Kazakin, ${ }^{6}$ and Brian Schwartz ${ }^{6}$ \\ ${ }^{1}$ Medical Genomics and Metabolic Genetics Branch, National Human Genome Research Institute, National \\ Institutes of Health, Bethesda, Maryland 20892, USA; ${ }^{2}$ Hunter Genetics, Hunter-New England Local Health \\ District, New South Wales Department of Health, Waratah, New South Wales 2298, Australia; ${ }^{3}$ Department \\ of Paediatrics, Western Sydney University School of Medicine, Penrith, New South Wales 2751, Australia; \\ ${ }^{4}$ Pharmacy, John Hunter Hospital, Hunter-New England Local Health District, New South Wales Department of \\ Health, New South Wales 2310, Australia; ${ }^{5}$ Medical Imaging, Paediatric Radiology, Hunter-New England Local \\ Health District, New South Wales Department of Health, New South Wales 2310, Australia; ${ }^{6}$ Arqule Inc, \\ Burlington, Massachusetts 01803, USA
}

Abstract A 20-yr-old man with Proteus syndrome (PS) and somatic mosaicism of the AKT1 c.49G > A p.(E17K) variant had asymmetric overgrowth of the right frontal and facial bones, asymmetric spinal overgrowth with thoracolumbar scoliosis, dilatation of the inferior vena cava, testicular cystadenoma, bilateral knee deformities, macrodactyly, and apparent intellectual disability. Miransertib (ARQ 092) is an oral, allosteric, selective pan-AKT inhibitor initially developed for cancer therapeutics, now being evaluated for the treatment of PS. After baseline evaluation, the patient started unblinded treatment of $10 \mathrm{mg}$ oral miransertib daily ( $5 \mathrm{mg} / \mathrm{m}^{2} /$ day), escalated to $30 \mathrm{mg}$ daily $\left(\sim 15 \mathrm{mg} / \mathrm{m}^{2} /\right.$ day), and then to $50 \mathrm{mg}$ daily ( $25 \mathrm{mg} / \mathrm{m}^{2} /$ day) after 3 mo of treatment. Adverse events included dry mouth, one episode of gingivostomatitis, and loose, painful dentition due to preexisting periodontal disease, all of which resolved spontaneously. After 11 mo of treatment, the patient reported improved general well-being, increased mobility of the ankle, spine, and hands, a subjective decrease in size of the right facial bone overgrowth, and reduced areas of cerebriform connective tissue nevi on the soles. Whole-body MRI findings were stable without apparent disease progression. We conclude that $1 \mathrm{yr}$ of treatment with miransertib was beneficial in this case.

[Supplemental material is available for this article.]

\section{INTRODUCTION}

Patients with Proteus syndrome (PS) have severe, progressive overgrowth that can affect nearly any region of the body (Biesecker 2006). It is progressive and causes death (Sapp et al. 2017), either by distortion or compression of vital structures by overgrown tissues, thromboembolism (Keppler-Noreuil et al. 2017), respiratory disease associated with pulmonary cysts (Newman et al. 1994; Lim et al. 2011), or malignant transformation in an overgrown tissue such as a parotid tumor, ovarian cystadenoma, or testicular tumor (Cohen 2005). Common syndromic manifestations include large superficial or deep lipomatous overgrowths, intellectual disability, seizures and other neurological problems, and severe skeletal deformities with skull overgrowth, kyphoscoliosis, asymmetric macrodactyly and valgus, or varus deformities of the knees. The cerebriform connective tissue nevus 
COLD SPRING HARBOR Molecular Case Studies
Treatment of Proteus syndrome with miransertib

(CCTN) of the soles found in many patients is a specific, but not pathognomonic finding. It makes weight-bearing and footwear uncomfortable, and hygiene is difficult to maintain (Cohen 2014).

A somatic variant in the AKT1 gene-c.49G > A, p.Glu17Lys-is the only reported cause of PS (Lindhurst et al. 2011). AKT1 is a serine-threonine kinase that participates in the AKT/ $\mathrm{PI} 3 \mathrm{~K} / \mathrm{mTOR}$ pathway: The p.Glu17Lys variant constitutively activates the protein, limiting apoptosis and promoting growth, among other effects (Carpten et al. 2007). Miransertib (ARQ 092) is an oral, allosteric, selective pan-AKT inhibitor that inhibits both active and inactive forms of AKT. In in vitro and in vivo experiments, it demonstrated antiproliferative activity in cancer and in cells derived from patients with PIK3CA-related overgrowth syndrome (PROS) and PS (Lindhurst et al. 2015; Yu et al. 2015). An abstract describing patients with ovarian cancers bearing PIK3CA or AKT1 variants treated with miransertib reported favorable efficacy and side effects (Hyman et al. 2018). More recently, metastatic tumors and some skeletal deformities improved after 22 mo of treatment of a teenager with PS and metastatic ovarian cancer (Leoni et al. 2019). The only available alternative treatments of PS are palliative. Presently, 29 participants with either PS or PROS have been treated with miransertib in two ongoing research projects and under compassionate use programs (B Schwartz, unpubl. data). Six of these individuals, all with PS, were treated with miransertib in a research project being run by the U.S. National Institutes of Health (NIH) (KepplerNoreuil et al. 2019). That study reached a pharmacodynamic endpoint of $50 \%$ inhibition of AKT in five of six treated patients and suggestions of efficacy for CCTN reduction and pain reduction, although these were secondary endpoints not evaluated for statistical significance. Based on these suggestions of efficacy and apparently tolerable adverse effects, we treated a young man with PS with miransertib on a compassionate use basis and report that experience here.

\section{RESULTS}

\section{Clinical Presentation and Family History}

The patient was born at $41 \mathrm{wk}$ gestation by vaginal delivery weighing $3.6 \mathrm{~kg}$ with no prenatal complications. Both parents had learning difficulties; otherwise there was no relevant family history. His medical history was complicated by nonaccidental fractures of the femur, tibia, and clavicle at age $5 \mathrm{wk}$ and care was assumed by the Public Guardian. His current foster parents brought him to genetics at age 16 mo with global developmental delay, overgrowth of the right frontal bone, and macrodactyly of the right middle finger. A clinical diagnosis of PS was based on the developmental delay, macrodactyly, and frontal overgrowth (Biesecker et al. 1999). Subsequent developments are listed in Table 1.

The Guardianship Board of the New South Wales Civil and Administrative Tribunal gave informed consent to applications by the patient and his foster parents for compassionate use of miransertib. This was approved by the Therapeutic Goods Administration, Australia, and the Quality Use of Medicines Committee of the John Hunter Hospital. After an initial dose of $10 \mathrm{mg}$ daily the dose was increased after $1 \mathrm{mo}$ to $30 \mathrm{mg}$ per day and one month later to $50 \mathrm{mg}$ per day $\left(\sim 25 \mathrm{mg} / \mathrm{m}^{2}\right)$.

\section{Genomic Analysis}

A mosaic c.49G > A variant in AKT1 was identified on Sanger sequencing of DNA from fibroblasts cultured from an affected area of skin (Table 2). Blood was not tested for this variant as the underlying variant is not usually found in blood (Lindhurst et al. 2011), and DNA from affected tissue was available. 
Table 1. Clinical timeline

\begin{tabular}{|c|c|}
\hline Age (yr) & Clinical details \\
\hline 2 & $\begin{array}{l}\text { Left convergent strabismus } \\
\text { Clinically diagnosed lipomatous overgrowths of the right anterior abdominal wall, right axilla, } \\
\text { and chin, with significant cosmetic deformity } \\
\text { Overgrowth of right leg requiring osteotomy with stapling of the distal femoral growth plate at } \\
\text { age } 31 \text { mo } \\
\text { Amputation of overgrown left second and third toes }\end{array}$ \\
\hline 3 & $\begin{array}{l}\text { Amputation of right third toe } \\
\text { Cerebriform connective tissue nevus of the soles } \\
\text { Vineland Adaptive Behavior Scales, Interview Edition, standardized with mean 100,95\% } \\
\text { confidence interval } \pm 15 \text {, assessed at age } 41 \text { mo (Supplement 1) was } 61 \pm 6 \text { (0.5th centile) }\end{array}$ \\
\hline 4 & $\begin{array}{l}\text { Valgus deformity of right knee and varus deformity of the left knee } \\
\text { Varicose veins of right leg and continued growth of amputated toe stumps } \\
\text { Griffiths assessment at age } 58 \text { mo indicated } 36 \text { mo attainment }\end{array}$ \\
\hline 5 & Attention deficit hyperactivity disorder treated with methylphenidate. \\
\hline 6 & $\begin{array}{l}\text { Factor V Leiden detected at National Institutes of Health on screening for thrombophilia, } \\
\text { performed because of thromboembolism reported in other affected patients } \\
\text { Verbal IQ was } 57 \text { and performance IQ was } 65 \text { on WISC-IV }\end{array}$ \\
\hline 7 & Asymmetric testicular growth \\
\hline 11 & Superficial thrombophlebitis of varicose veins in the right leg \\
\hline 15 & $\begin{array}{l}\text { Progressive valgus deformity of one knee and varus deformity of the other were treated } \\
\text { successfully with bilateral epiphyseal stapling that enabled the patient to continue activities } \\
\text { like walking and riding a bicycle }\end{array}$ \\
\hline 17 & $\begin{array}{l}\text { Excision of benign right epididymal cystadenoma; another epididymal lump on that side has } \\
\text { not grown and is being observed } \\
\text { Thrombosis of superficial varicose veins in the right leg at age } 17 \mathrm{yr} \text { has been managed with } \\
\text { clodipogrel and perioperative prophylaxis with enoxaparin sodium }\end{array}$ \\
\hline 20 & $\begin{array}{l}\text { Repeated surgery to the turbinate bones and sinuses was planned for progressive overgrowth } \\
\text { of the right frontal lesion, which was obstructing the right superomedial visual field, the } \\
\text { nasal passages, and frontal sinus } \\
\text { Weight } 60 \mathrm{~kg} \text {, height } 201 \mathrm{~cm}(>97 \text { th centile), head circumference } 59 \mathrm{~cm}(>97 \text { th centile) } \\
\text { Middle finger lengths were right } 11 \mathrm{~cm}(>>97 \text { th centile) and left } 8.3 \mathrm{~cm}(\sim 75 \text { th centile), } \\
\text { midhand lengths were right } 23 \mathrm{~cm}(>97 \text { th centile) and left } 19 \mathrm{~cm}(\sim 60 \text { th centile); the right } \\
\text { foot measured } 26.5 \mathrm{~cm} \text { ( } 50 \text { th-75th centile), left } 29 \mathrm{~cm}(>97 \text { th centile); and upper to lower } \\
\text { segment ratio was } 0.94 \text { and the arm span was } 185 \mathrm{~cm} \\
\text { Blood pressure } 116 / 58\end{array}$ \\
\hline
\end{tabular}

\section{Treatment Outcomes and Adverse Effects}

The patient and his family reported that dryness of the mouth appeared soon after starting treatment, and this persisted unchanged. An episode of gingivostomatitis was treated with local analgesics. No previous similar lesions could be recalled. His pediatric dentist attributed loose painful dentition, noted after 3 mo treatment at the $25 \mathrm{mg} / \mathrm{m}^{2} /$ day dose and

\begin{tabular}{|c|c|c|c|c|c|c|c|c|}
\hline Gene & Chromosome & $\begin{array}{l}\text { HGVS DNA } \\
\text { reference }\end{array}$ & $\begin{array}{l}\text { HGVS protein } \\
\text { reference }\end{array}$ & $\begin{array}{l}\text { Variant type } \\
\text { (substitution, } \\
\text { deletion, etc.) }\end{array}$ & $\begin{array}{c}\text { Predicted } \\
\text { effect }\end{array}$ & $\begin{array}{l}\text { dbSNP/ } \\
\text { dbVar ID }\end{array}$ & $\begin{array}{c}\text { Genotype } \\
\text { (heterozygous/ } \\
\text { homozygous) }\end{array}$ & ClinVar ID \\
\hline AKT1 & 14 & $\begin{array}{l}\text { NM_005163.2 } \\
\text { (AKT1):c.49G > } \\
\text { A (p.Glu17Lys) }\end{array}$ & $\begin{array}{l}\text { NP_001014432 } \\
\text { E17K }\end{array}$ & Substitution & Activation & rs121434592 & Heterozygous & VCV000013983.2 \\
\hline
\end{tabular}



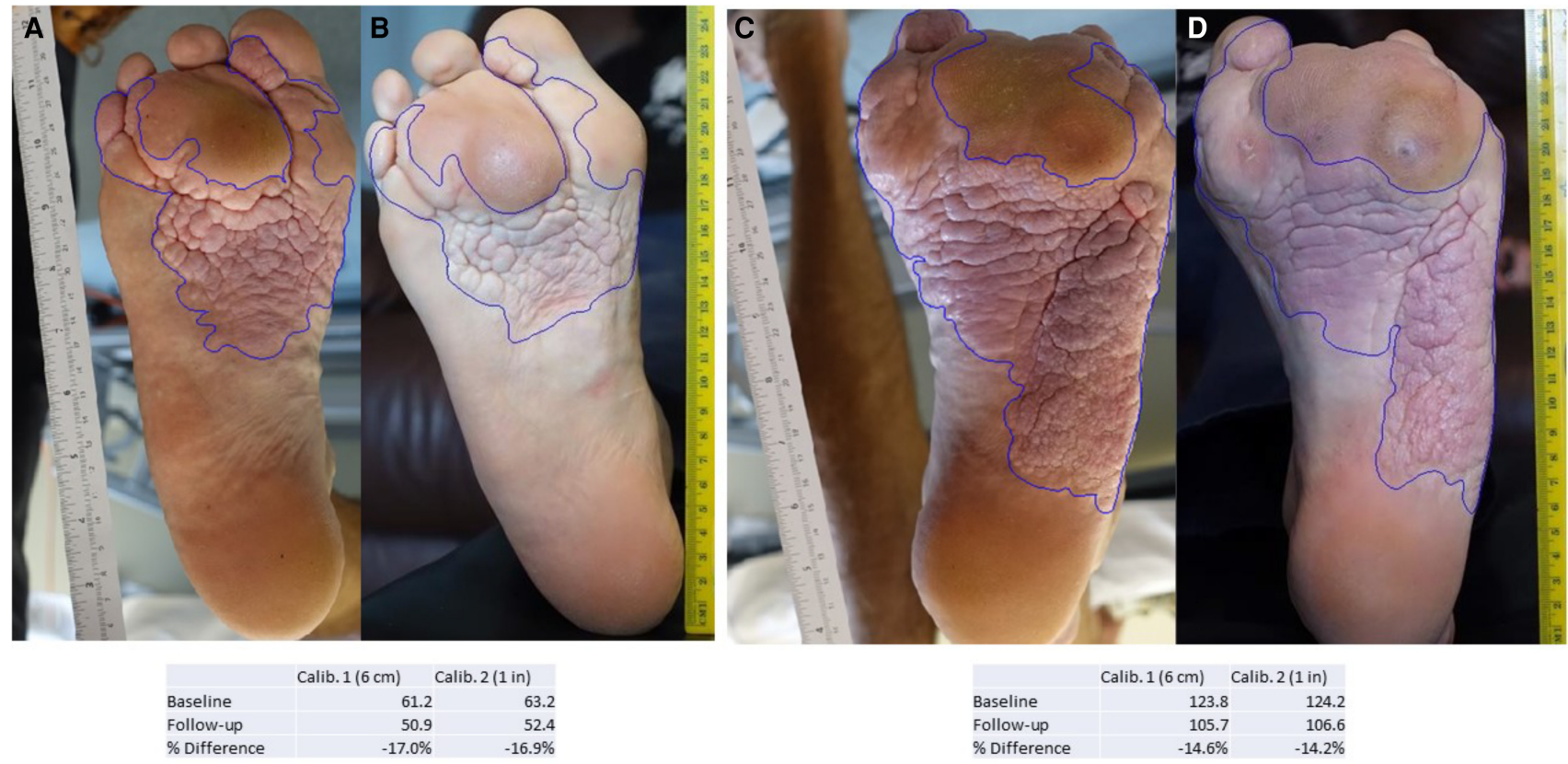

Figure 1. Areas of cerebriform lesion on soles before $(A, C)$ and at follow-up after 12 mo treatment with miransertib $50 \mathrm{mg}\left(25 \mathrm{mg} / \mathrm{m}^{2}\right)$ per day $(B, D)$, for right $(A, B)$ and left $(C, D)$ sole. Underneath the photographs are calculated areas of the lesion on each sole (see Methods).

attributable to known preexistent periodontal disease. The gingivostomatitis and painful dentition both resolved after a week of supportive treatment. Monthly blood biomarkers (see Methods; Supplements 2a and 2b) changed little in his nearly 1 yr of treatment. His hemoglobin was mildly low pretreatment and remained mildly low or normal during treatment. Serum bicarbonate was two units above the reference range on one occasion and one unit above on another. The only trends we noted were that of a slightly declining alkaline phosphatase (slope $=-0.09 r^{2}=0.784, P<0.0001$ ) and a slightly rising fasting glucose (slope $=$ $0.001, r^{2}=0.49, P=0.0037$ ) and total cholesterol (slope $=0.0007, r^{2}=0.48, P=0.0044$ ), although it is important to note that all three of these remained well within their normal ranges. ECG and echocardiogram at baseline and after $12 \mathrm{mo}$ on miransertib $25 \mathrm{mg} / \mathrm{m}^{2} /$ day were normal. There was a $14 \%-17 \%$ reduction in absolute area of the CCTN of the soles after 12 mo of treatment (Fig. 1). Subjectively, the patient and his family have noted reduction in the volume of a lipomatous overgrowth of the right lower abdominal wall, and greater mobility and comfort of joints of the arms and hands. There was either improvement or stability in all indices of general mood and well-being assessed by questionnaire (Supplements 3-5). A repeat MRI scan 11 mo after commencement of treatment showed no obvious increase in the size of overgrown soft tissue and bone of the right frontal region or lipomatous overgrowth in the right abdominal wall (Fig. 2).

\section{DISCUSSION}

This rare syndrome was first described in the modern medical literature in 1976 (Temtamy and Rogers 1976) and given its name in 1983 (Wiedemann et al. 1983) to reflect the many forms adopted by a Greek sea god: Overgrowth can affect any area of the body, and the disorder is highly phenotypically heterogeneous (Biesecker and Sapp 1993). The overgrowth in 

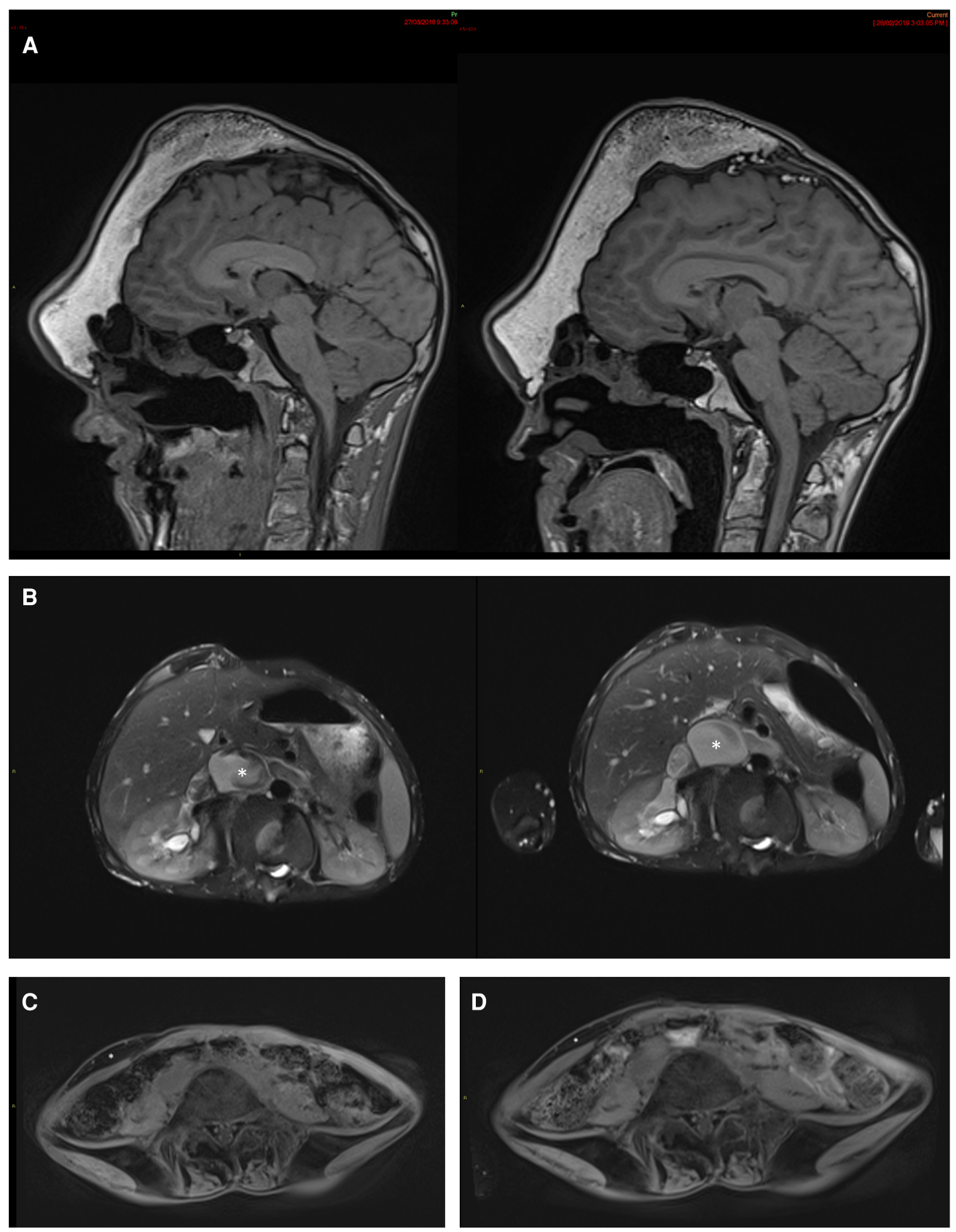

Figure 2. Representative MRI photographs from before treatment and after 11 mo treatment. (A) Sagittal brain T1 MRI from baseline (left) and after $11 \mathrm{mo}$ (right) showing no obvious progression of skull deformity or new lesion. (B) Axial T2 abdominal fat-saturated MRI from baseline (left) and after 11 months (right) showing dilatation of inferior vena cava $\left(^{*}\right)$ and renal veins. (C) Baseline abdominal wall axial T1 fat saturation MRI scan showing lipomatous overgrowth (*) of the right anterior abdominal wall. (D) After 11 mo treatment, abdominal wall axial T1 fat saturation MRI scan showing width of lipomatous overgrowth $\left(^{*}\right)$ of the right anterior abdominal wall.

PS is associated with an activation of the AKT1 protein (Lindhurst et al. 2011). This name derives from the AKR laboratory mouse (Furth 1978), which commonly had spontaneous leukemia and tumors including thymomas, cells from one of which were found to harbor a retrovirus designated AKT8 (Staal et al. 1977). The provirus sequence included part of a 
mouse host oncogene called v-akt, and in humans an orthologous sequence was identified in a gene named AKT1, which was found to be amplified in gastric adenocarcinomas (Staal 1987). AKT1 is mutated in a number of human tumors (COSMIC database), and in essentially all reports, the variant is the same as the variant that is found in the mosaic state in individuals with PS. This variant causes ligand-independent activation of the AKT1 signal, downstream from tyrosine kinase growth factor receptors in the AKT/PIK3CA/mTOR pathway (Carpten et al. 2007). Miransertib is an allosteric inhibitor of AKT1 that has been shown in vitro to regulate the growth of tumors that have this variant. It has also been shown to inhibit AKT1 signaling in cells from patients with PS and a phase 0/1 pharmacodynamic study has shown an acceptable adverse effects profile and some preliminary data for efficacy. Based on these data and given the serious medical issues in this patient, compassionate use was considered to be appropriate.

His initial dose was about $5 \mathrm{mg} / \mathrm{m}^{2} /$ day, similar to the dosing of the NIH study (KepplerNoreuil et al. 2019). This was escalated to $15 \mathrm{mg} / \mathrm{m}^{2} /$ day and then $25 \mathrm{mg} / \mathrm{m}^{2} /$ day, as he had no recognizable adverse effects other than a dry mouth that appeared on the lower doses and persisted throughout treatment. There were transient gingivostomatitis and loose, painful teeth, which appeared to resolve spontaneously; viral studies were not performed. In the lower-dose NIH study, grade 1 mucositis (CTCAE criteria) was observed four times (KepplerNoreuil et al. 2019). We monitored a number of clinical laboratory values for adverse effects, none significantly changed from normal to abnormal. There were some subtle trends of glucose, cholesterol, and alkaline phosphatase that were statistically significant, but are of uncertain clinical significance. One grade 1 hyperglycemia was observed in the NIH study. In contrast to the slight decline in alkaline phosphatase observed in this young man, there was a single occurrence of grade 2 elevation in the NIH study. There was a single observation of grade 1 cholesterol elevation in the $\mathrm{NIH}$ study. All three of these parameters remained within normal ranges in the subject of this report. His D-dimer levels were abnormal before treatment and remained abnormal.

We evaluated the individual for signs of the apparent benefit of treatment. The area of the CCTN lesion of the foot was decreased, which is consistent with the results shown in the phase 0/1 pharmacodynamic trial (Keppler-Noreuil et al. 2019). The radiologist did not appreciate any enlargement of any of the overgrowth that was evaluable on the preand post-treatment MRI scans. The foster parents believed that the lipomas had decreased in volume. There was either improvement or stability in all indices of general mood and wellbeing assessed by the questionnaire.

The rarity and slow rate of progression of PS pose considerable challenges to the design of studies to measure the efficacy of any treatment. Long-term clinical trials, with novel study designs, will need to be undertaken to assess the benefits and adverse effects of chronic treatment. Until such trials can be completed, small studies and anecdotal reports of treated individuals are useful to begin to understand the risks and benefits of primary treatment of this disease. The results we report here are consistent with some evidence of benefit and modest apparent adverse effects. As in any other report of anecdotal data, caution must be exercised in interpreting the data, but in individuals such as the young man reported here, we conclude that the compassionate use was appropriate and we are continuing his treatment based on the assessment by his care providers and foster parents of the risks and benefits of this experimental treatment at the $25 \mathrm{mg} / \mathrm{m}^{2} /$ day dosing level.

\section{METHODS}

Baseline whole-body MRI, full blood count, clotting studies with D-dimers, liver function tests, urea electrolytes creatinine, calcium magnesium phosphate, glucose, $\mathrm{HbA} 1 \mathrm{C}$, lipids, 
C OLD SPR ING HARBOR Molecular Case Studies
Treatment of Proteus syndrome with miransertib
Competing Interest Statement B.S., J.K., and K.T. are medical staff of Arqule, Inc

\section{Referees}

Marcella Zollino

Gholson Lyon

Anonymous

Received June 28, 2019; accepted in revised form October 4, 2019. urinalysis, ECG, and echocardiogram were performed at baseline within a month before the commencement of treatment, and selected blood tests were repeated monthly. The patient's family was given a comprehensive list of side effects previously reported with miransertib and asked to report on the appearance of any of these (or other) symptoms.

Whole-body MRI was repeated $1 \mathrm{yr}$ after commencement of treatment and analyzed unblinded by a radiologist for apparent changes in deformity and overgrowth. Two-dimensional photographs available for the cerebriform lesions on the soles before treatment and after 12 mo of treatment (Fig. 1) were analyzed by Dermapix software (www.quantificare.com). This quantified the area of the sole covered by the lesion (Fig. 1). The Self-reported Pain Intensity Index (Melzack 1987; Cohen et al. 2008a,b), Impact of Pediatric Illness ScaleAdult (Wolters et al. 2010, 2013, 2015; Martin et al. 2016), and Adult Pain Interference Index form (Wicksell et al. 2009; Martin et al. 2015) were collated with parental questionnaires and were analyzed for marked or progressive changes without statistical analysis.

\section{ADDITIONAL INFORMATION}

\section{Database Deposition and Access}

The results have been deposited to COSMIC (https://cancer.sanger.ac.uk/cosmic) under accession number COSP31880. The variant was deposited to ClinVar (https://www.ncbi.nlm .nih.gov/clinvar/) and can be found under accession number VCV000013983.2.

\section{Ethics Statement}

We have obtained consent from the guardian of the subject of this report. The Guardianship Division of the New South Wales Civil and Administrative Tribunal, the Australian Government Department of Health Therapeutic Goods Administration, and the John Hunter Hospital Quality Use of Medicines Committee provided prospective written consent for compassionate use of miransertib.

\section{Acknowledgments}

The authors thank the patient's foster family for their advocacy.

\section{Author Contributions}

L.G.B. and M.E. wrote the manuscript. M.E., S.O., and L.G.B. have provided clinical supervision and molecular analysis.

\section{Funding}

Miransertib was provided by Arqule, Inc. L.G.B. receives in-kind research support from ArQule, Inc.

\section{REFERENCES}

Biesecker LG. 2006. The challenges of Proteus syndrome: diagnosis and management. Eur J Hum Genet 14: 1151-1157. doi:10.1038/sj.ejhg.5201638

Biesecker LG, Sapp JC. 1993. Proteus Syndrome. In GeneReviews ${ }^{\circledR}$ (ed. Adam MP, et al.). University of Washington, Seattle, WA.

Biesecker LG, Happle R, Mulliken JB, Weksberg R, Graham JM, Viljoen DL, Cohen MM. 1999. Proteus syndrome: diagnostic criteria, differential diagnosis, and patient evaluation. Am J Med Genet 84: 389-395. doi:10.1002/(SICI)1096-8628(19990611)84:5<389::AID-AJMG1>3.0.CO;2-O 
Carpten JD, Faber AL, Horn C, Donoho GP, Briggs SL, Robbins CM, Hostetter G, Boguslawski S, Moses TY, Savage $\mathrm{S}$, et al. 2007. A transforming mutation in the pleckstrin homology domain of AKT1 in cancer. Nature 448: 439-444. doi:10.1038/nature05933

Cohen MM Jr. 2005. Proteus syndrome: an update. Am J Med Genet C Semin Med Genet 137: 38-52. doi:10 1002/ajmg.c.30063

Cohen MM Jr. 2014. Proteus syndrome review: molecular, clinical, and pathologic features. Clin Genet 85: 111-119. doi:10.1111/cge.12266

Cohen LL, La Greca AM, Blount RL, Kazak AE, Holmbeck GN, Lemanek KL. 2008a. Introduction to special issue: evidence-based assessment in pediatric psychology. J Pediatr Psychol 33: 911-915. doi:10.1093/ jpepsy/jsj115

Cohen LL, Lemanek K, Blount RL, Dahlquist LM, Lim CS, Palermo TM, McKenna KD, Weiss KE. 2008b. Evidence-based assessment of pediatric pain. J Pediatr Psychol 33: 939-955; discussion 956-957. doi:10.1093/jpepsy/jsm103

Furth J. 1978. The creation of the AKR strain, whose DNA contains the genome of a leukemia virus. In Origins of inbred mice: proceedings of a workshop, Bethesda, Maryland, February 14-16, 1978 (ed. Morse HC, et al.), pp. xvi, 719. Academic, New York.

Hyman D, Bonafede M, O'Cearbhaill R, Grisham R, Zamarin D, Tew W, Aghajanian C, Cadoo K, Friedman C, Savage RE, et al. 2018. Abstract CT035: a phase lb study of miransertib (ARQ 092) in combination with anastrozole in patients with PIK3CA or AKT1-mutant $\mathrm{ER}^{+}$endometrial or ovarian cancer. Cancer Res 78: CT035. doi:10.1158/1538-7445.AM2018-СT035

Keppler-Noreuil KM, Lozier JN, Sapp JC, Biesecker LG. 2017. Characterization of thrombosis in patients with Proteus syndrome. Am J Med Genet A 173: 2359-2365. doi:10.1002/ajmg.a.38311

Keppler-Noreuil KM, Sapp JC, Lindhurst MJ, Darling TN, Burton-Akright J, Bagheri M, Dombi E, Gruber A Jarosinski PF, Martin S, et al. 2019. Pharmacodynamic study of miransertib in individuals with Proteus syndrome. Am J Hum Genet 104: 484-491. doi:10.1016/j.ajhg.2019.01.015

Leoni C, Gullo G, Resta N, Fagotti A, Onesimo R, Schwartz B, Kazakin J, Abbadessa G, Crown J, Collins CD et al. 2019. First evidence of a therapeutic effect of miransertib in a teenager with Proteus syndrome and ovarian carcinoma. Am J Med Genet A 179: 1319-1324. doi:10.1002/ajmg.a.61160.

Lim GY, Kim OH, Kim HW, Lee KS, Kang KH, Song HR, Cho TJ. 2011. Pulmonary manifestations in Proteus syndrome: pulmonary varicosities and bullous lung disease. Am J Med Genet A 155A: 865-869. doi:10 .1002/ajmg.a.33926

Lindhurst MJ, Sapp JC, Teer JK, Johnston JJ, Finn EM, Peters K, Turner J, Cannons JL, Bick D, Blakemore L, et al. 2011. A mosaic activating mutation in AKT1 associated with the Proteus syndrome. N Engl J Med 365: 611-619. doi:10.1056/NEJMoa1104017

Lindhurst MJ, Yourick MR, Yu Y, Savage RE, Ferrari D, Biesecker LG. 2015. Repression of AKT signaling by ARQ 092 in cells and tissues from patients with Proteus syndrome. Sci Rep 5: 17162. doi:10.1038/ srep17162

Martin S, Nelson Schmitt S, Wolters PL, Abel B, Toledo-Tamula MA, Baldwin A, Wicksell RK, Merchant M, Widemann B. 2015. Development and validation of the English Pain Interference Index and Pain Interference Index-Parent report. Pain Med 16: 367-373. doi:10.1111/pme.12620

Martin S, Wolters PL, Toledo-Tamula MA, Schmitt SN, Baldwin A, Starosta A, Gillespie A, Widemann B. 2016. Acceptance and commitment therapy in youth with neurofibromatosis type 1 (NF1) and chronic pain and their parents: a pilot study of feasibility and preliminary efficacy. Am J Med Genet A 170: 1462-1470. doi:10.1002/ajmg.a.37623

Melzack R. 1987. The short-form McGill pain questionnaire. Pain 30: 191-197. doi:10.1016/0304-3959(87) 91074-8

Newman B, Urbach AH, Orenstein D, Dickman PS. 1994. Proteus syndrome: emphasis on the pulmonary manifestations. Pediatr Radiol 24: 189-193. doi:10.1007/BF02012188

Sapp JC, Hu L, Zhao J, Gruber A, Schwartz B, Ferrari D, Biesecker LG. 2017. Quantifying survival in patients with Proteus syndrome. Genet Med 19: 1376-1379. doi:10.1038/gim.2017.65

Staal SP. 1987. Molecular cloning of the akt oncogene and its human homologues AKT1 and AKT2: amplification of AKT1 in a primary human gastric adenocarcinoma. Proc Natl Acad Sci 84: 5034-5037. doi:10 $.1073 /$ pnas.84.14.5034

Staal SP, Hartley JW, Rowe WP. 1977. Isolation of transforming murine leukemia viruses from mice with a high incidence of spontaneous lymphoma. Proc Natl Acad Sci 74: 3065-3067. doi:10.1073/pnas.74.7 .3065

Temtamy SA, Rogers JG. 1976. Macrodactyly, hemihypertrophy, and connective tissue nevi: report of a new syndrome and review of the literature. J Pediatr 89: 924-927. doi:10.1016/S0022-3476(76)80597-5

Wicksell RK, Melin L, Lekander M, Olsson GL. 2009. Evaluating the effectiveness of exposure and acceptance strategies to improve functioning and quality of life in longstanding pediatric pain-a randomized controlled trial. Pain 141: 248-257. doi:10.1016/j.pain.2008.11.006 
Wiedemann HR, Burgio GR, Aldenhoff P, Kunze J, Kaufmann HJ, Schirg E. 1983. The Proteus syndrome. Partial gigantism of the hands and/or feet, nevi, hemihypertrophy, subcutaneous tumors, macrocephaly or other skull anomalies and possible accelerated growth and visceral affections. Eur J Pediatr 140: 5-12. doi:10 .1007/BF00661895

Wolters P, Martin S, Walker K, Widemann B. 2010. Impact of Illness (IPI) Scale parent form: validity and reliability data for children with neurofibromatosis type 1 (NF1) and plexiform neuroma (PF). In Children's Tumor Foundation NF Conference, p. 50. Children's Tumor Foundation, Baltimore, MD.

Wolters P, Martin S, Walker K, Widemann B. 2013. Quality of life of adolescents with neurofibromatosis type 1 (NF1) and plexiform neurofibromas (PNs): reliability and validity of the impact of pediatric illness (IPI) Scale self-report form. In The National Conference in Pediatric Psychology. Society of Pediatric Psychology, New Orleans, LA.

Wolters PL, Burns KM, Martin S, Baldwin A, Dombi E, Toledo-Tamula MA, Dudley WN, Gillespie A, Widemann BC. 2015. Pain interference in youth with neurofibromatosis type 1 and plexiform neurofibromas and relation to disease severity, social-emotional functioning, and quality of life. Am J Med Genet A 167: 2103 2113. doi:10.1002/ajmg.a.37123

Yu Y, Savage RE, Eathiraj S, Meade J, Wick MJ, Hall T, Abbadessa G, Schwartz B. 2015. Targeting AKT1-E17K and the PI3K/AKT pathway with an allosteric AKT inhibitor, ARQ 092. PLoS One 10: e0140479. doi:10 .1371/journal.pone.0140479 


\section{COLD SPRING HARBOR Molecular Case Studies}

\section{Clinical report: one year of treatment of Proteus syndrome with miransertib (ARQ 092)}

Leslie G. Biesecker, Matthew Edwards, Sheridan O'Donnell, et al.

Cold Spring Harb Mol Case Stud 2020, 6: a004549

Access the most recent version at doi: $10.1101 / \mathrm{mcs} . \mathrm{a} 004549$
Supplementary http://molecularcasestudies.cshlp.org/content/suppl/2020/01/29/mcs.a004549.D Material C1

References This article cites 26 articles, 2 of which can be accessed free at: http://molecularcasestudies.cshlp.org/content/6/1/a004549.full.html\#ref-list-1

License This article is distributed under the terms of the Creative Commons Attribution-NonCommercial License, which permits reuse and redistribution, except for commercial purposes, provided that the original author and source are credited.

Email Alerting Receive free email alerts when new articles cite this article - sign up in the box at the Service top right corner of the article or click here. 